\title{
Copulatory behavior supports a new insight into taxonomic status of root vole Alexandromys oeconomus (Rodentia, Arvicolinae)
}

\author{
Tanya A. Zorenko* \& Nasko I. Atanasov
}

\begin{abstract}
The aim of the study was to evaluate the phylogeny and relationships of the root vole Alexandromys oeconomus with the other species of the tribe Microtini, using the comparison of the characteristics of sexual behavior. Thirteen copulatory behavior patterns that form a specific stereotype of the species' mating behavior are used. The results showed the multiple thrusting stereotype of copulation, which includes separate intromissions and a very first mount with intromission, is ending with ejaculation (from $10 \%$ to $48 \%$, depending by the investigated population). The number of ejaculations is comparatively big, varying from 4 to 7 (an average of 4.6) and the genital stimulation rate is from 68 to 260 thrusts. The males of the root vole noted active courtship for the female, which is accompanied by singing, waltzing and marking of the substrate. Marking the territory is manifested by rubbing the femoral region on the substrate, in which the secretion of the hip glands is applied to it. Analysis of the distances (or similarities) between species according to patterns of sexual behavior using the method of cluster analysis indicates the proximity of $A$. oeconomus to species of the genus Alexandromys and a considerable distance from representatives of the genus Microtus (Microtus s.str. and Sumeriomys). Significant interpopulation differences in copulatory behavior of the Central Asian phylogroup are established (54\% of all the behavioral traits studied). The transformation of the stereotype of mating in individuals from Beringia phylogroup in comparison with the Central Asian one is particularly significant and reaches $77 \%$ of all the behavioral traits. The data obtained by the analysis of the copulatory behavior of the Alexandromys oeconomus support the separation of the species from genus Microtus.

How to cite this article: Zorenko T.A., Atanasov N.A. 2018. Copulatory behavior supports a new insight into taxonomic status of root vole Alexandromys oeconomus (Rodentia, Arvicolinae) // Russian J. Theriol. Vol.17. No.1. P.48-57. doi: 10.15298/rusjtheriol.17.1.05
\end{abstract}

KEY WORDS: Alexandromys oeconomus, Alexandromys, Microtus, copulatory behaviour, scent marking, hip glands, copulatory stereotype, taxonomy, phylogeny.

Tanya A. Zorenko [zorenkot@lanet.lv], University of Latvia, Elgavas 1, RigaLV-1586, Elgavas 1, Latvia; Nasko I. Atanasov [naskoat@gmail.com], Institute of Biodiversity and Ecosystem Research, Bulgarian Academy of Sciences, Tsar Osvoboditel blvd. 1, 1000 Sofia, Bulgaria.

\section{Новый таксономический статус полевки-экономки Alexandromys oeconomus (Rodentia, Arvicolinae) подтверждается результатами анализа их полового поведения}

\section{Т.А. Зоренко, Н.И. Атанасов}

РЕЗЮМЕ. Целью работы было оценить филогению и родственные связи полевки-экономки (Alexandromys oeconomus) с другими видами трибы Microtini, используя для сравнения особенности полового поведения. Мы использовали 13 паттернов, которые формируют специфический стереотип спаривания вида. Результаты показывают, что для вида характерен многотолчковый стереотип спаривания, который включает малое число интромиссий и уже при первой же садке с интромиссией происходит эякуляция (10-48\% в зависимости от популяции). Число эякуляций сравнительно большое - от 4 до 7 (в среднем 4,6); уровень генитальной стимуляции варьирует от 68 до 260 толчков. У самцов экономки отмечено активное ухаживание за самкой, которое сопровождается пением, вальсированием и мечением субстрата. Мечение проявляется в виде потирания бедренной областью субстрата, при котором на него наносится секрет железы. Анализ дистанций (сходства) между видами по паттернам полового поведения с помощью кластерного метода указывает на близость A. oeconomus к видам рода Alexandromys и значительную удаленность от представителей рода Microtus (Microtus s.str. и Sumeriomys). Отмечены заметные межпопуляционные различия полового поведения в пределах центральноазиатской филогруппы - 54\% (от всех изученных

* Corresponding author 
признаков), тогда как преобразования стереотипа спаривания у особей берингийской филогруппы особенно значительны и по сравнению с центральноазиатской различия достигают 77\%. Данные, полученные по половому поведению, поддерживают выведение Alexandromys oeconomus из рода Microtus.

КЛЮЧЕВЫЕ СЛОВА: Alexandromys oеconomus, Alexandromys, Microtus, половое поведение, мечение, бедренные железы, стереотип спаривания, таксономия, филогения.

Despite the seeming variety of sexual behavior in the mammals, only four characteristics, namely multiple intromissions, pelvic thrusting, multiple ejaculations and lock, provide the basis of their copulation behavior (Dewsbury, 1972). These characteristics vary in terms of frequency and expression over time, and the presence of one or another pattern (for example, multiple intromissions "yes" or multiple intromissions "no") provide the variation in copulation stereotypes. Species models of copulation are stereotyped and genetically conditioned; they are quantifiable and have relatively low plasticity. Qualitative aspects of copulation patterns do not vary extensively between wild and captive (laboratory-grown) populations (Estep et al., 1975; McGill, 1962). They depend a little on the quality of food and its storage with long breeding in captivity (Zorenko, 2013). The sexual activity of males do not depend also on the way that the females receptivity is induced: by using of hormones as in the studies of Dewsbury (Gray \& Dewsbury, 1973; Dewsbury \& Hartung, 1982) or because of the natural estrous cycles (Zorenko \& Malygin, 1984; Zorenko \& Atanasov, 2017). It has been shown that the behavior of the female does not change (Gray \& Dewsbury, 1973; Kenney et al., 1979). Behavior of females during estrous is normally triggered by the combined action of estrogen and progesterone (González-Flores et al., 2017).

Genetic variability of thresholds and frequency of realization of the different patterns can be the basis for micro-evolutionary behavioral changes and adaptation to a specific environment. In such cases the selection process supports these changes to enhance the reproductive efficiency.

Pre-copulatory or courtship behavior of rodents is very species-specific, with males and females displaying different patterns of behavior in order to attract a sexual partner. In voles, these behaviors do not only involve anogenital and urine investigation by partners, but scent marking, waltzing and singing, behavior represented to varying degrees in arvicolids (Zorenko, 1990). Analysis of the physical parameters of singing in the reed vole Alexandromys fortis Büchner, 1889 confirmed the objective presence of a specific signal in the repertoire of the males of this species (Zorenko \& Rutovskaya, 2006). Later Rutovskaya (2015) investigated and conducted a study of singing in a large number of vole species, including one male $A$. oeconomus from Chukotka.

Behavioral traits, like any other taxonomic signs, can represent a diagnostic function in indicating relationships between taxa (Dewsbury, 1972; Zorenko \&
Malygin, 1984; De Queiroz \& Wimberger, 1993; Zorenko \& Atanasov, 2017). The ethological analysis of copulation is important for understanding the evolution of behavior within the framework of a large subfamily of voles. In addition, it is of interest to compare the behavioral reconstructions of species-genera relationships with other reconstructions, performed using morphological and molecular genetic markers.

The root vole, Alexandromys oeconomus Pallas, 1776 , is one of the most studied species of the tribe Microtini. Until recently, the species was included in the genus Microtus (Gromov \& Erbayeva, 1995). In most molecular genetics and ecological publications, the root vole is reported as a Microtus oeconomus species despite identification of some features which are distinct from those of the Microtus genus (Conroy \& Cook, 2000; Brunhoff et al., 2003; Galbreath \& Cook, 2004; Iwasa et al., 2009; Bannikova et al., 2010; Haring et al., 2011). In the light of new taxonomic information it is now placed within the genus Alexandromys, subgenus Pallasiinus (Abramson \& Lissovsky, 2012). However, the later data do not support the concept of dividing Alexandromys into two lineages: Alexandromys s.str. and Pallasiinus Kretzoi, 1964 (Lissovsky et al., 2017). Using data from mitochondrial cytochrome b $(C y t b)$ gene sequences of Alexandromys oeconomus, four allopatric phylogroups have been identified - European, Northern European, Central Asian and Beringian (Brunhoff et al., 2003; Galbreath \& Cook, 2004; Iwasa et al., 2009). Haring et al. (2011) divided them into three phylogroups: European, Siberian and Beringian. Morphological data bring the voles from Western and Central Siberia together with the Northern European group (Abramson \& Tikhonova, 2005). The root vole is the only species of the Microtini tribe distributed in both the Old and New Worlds. Its penetration into North America could have occurred about 55000 years ago (Zakrzewski, 1985; Conroy \& Cook, 2000), while settlement in Alaska and the formation of the species area occurred during the Holocene (Galbreath \& Cook, 2004).

The aim of this study was to establish the phylogeny of studied populations of root voles by comparing the characteristics of sexual behavior. The following questions were addressed: (1) how does ethological analysis support the transfer of the species Microtus oeconomus from the genus Microtus to the genus Alexandromys? and (2) what are the behavioral differences between representatives of the three populations that belong to the different phylogroups? 


\section{Materials and methods}

Investigations were carried out using individual root voles from two populations. The bases of the laboratory colonies were A. oeconomus voles captured on meadows near Baikal Lake in the Khamar-Daban mountain range, Mishikha settlement (Baikal population - BP; 8 voles) and the surroundings of Zverinogolovskoye village, Pritobolsky region, Kurgan district (Ural population - UP; 6 voles). The studies were conducted in the period 1986-1987 (Zorenko, 1990). Ten pairs of animals from each population were studied. The experiments were performed with females in the estrous cycle, confirmed using vaginal smears (Zorenko \& Skinderskaya, 1996). Twelve pairs of animals from the vicinity of Fairbanks, Alaska (AP) were also studied (Dewsbury \& Hartung, 1982). In contrast to our experiments, estrous in Alaskan vole females was induced by injection of $0.06 \mathrm{mg}$ benzoate estradiol $69 \mathrm{~h}$ before testing and a single injection of $0.6 \mathrm{mg}$ progesterone 4 to $6 \mathrm{~h}$ before testing.

Since the male does not demonstrate aggression towards the receptive female, it is unimportant which sex of the animal is placed in the territory of the sexual partner. In our study during testing, the males were placed near caged females (cage dimensions $330 \times 550 \times$ $200 \mathrm{~mm}$ ). Dewsbury and Hartung (1982) placed the females in the territory of the males. The experiment ended when the criteria for satiety in males, indicated by $30 \mathrm{~min}$ without copulation, was achieved.

The mating behavior of voles included two stages: courtship (latency) and copulation, which consisted of a series of mounts, alternating with periods of rest. The elements of partner investigation, and friendly and marking behavior were recorded, as well as singing and waltzing during the courtship stage. Each series of copulation included mounts with vaginal insertion (intromission) and intravaginal thrusting and mounts with insertion and sperm transfer (ejaculation).

For the copulatory stage, the following indices were recorded: Latency $(\mathrm{L}, \mathrm{s})$ - period from introduction of the male in the territory of the female until the first intromission; Intromission Frequency (IF) - number of mounts with intromissions in a copulatory series, not including mounts with ejaculation; Mean number of thrusts per intromission (MT/I); Number of thrusts per Ejaculation (NTE $1^{\text {st }}$ series) - number of thrusts during mount with ejaculation; Total Number of Thrusts (NT $1^{\text {st }}$ series) - total number of thrusts during mounts with intromission and ejaculation in a series; Duration of Copulation (DC) - time interval(s) from the first intromission of a series to the end of ejaculation; Postejaculatory Interval (PEI) - interval(s) from the end of an ejaculation until the beginning of the next intromission; Ejaculation Frequency (EF) - number of ejaculations; $\Sigma$ IF - total number of intromissions during the whole copulatory period; $\Sigma$ NTI — total number of thrusts during mount with intromission for all series; $\Sigma$ NTE - total number of thrusts during mount with ejaculation for all series; $\Sigma \mathrm{NT}$ — total number of thrusts during mount with intromission and ejaculation during all the series; and \% one I - percentage of the series during whole test which consisted of one intromission and finished with ejaculation.

The animals were kept in standard laboratory conditions and the design of the test was as reported previously (Zorenko \& Atanasov, 2017). The voles were kept in parent groups until two months of age. The animals were then housed in separate cages. Individuals from F1-F2 generations aged 3 months were used in the experiments. During the experiments, direct observations and filming were conducted.

For all copulatory behavior parameters, average values and standard errors were calculated and compared using the Student's t-test. Statistical analysis of data was carried out using the program package PAST (version 3.06; Paleontological Statistics). Biometric comparison was performed using the t-test (two-sample t-test assuming unequal variance). Hierarchical cluster analysis as paired group algorithm was applied. It calculates Gower's (Fig. 2) or Cosine (Fig. 3) similarity index (constrained mode) and constructs dendrogram on the base of the distances between the sexual behavior parameters. When the unweighted pair-group average (UPGMA) was applied, the clusters were joined based on the average distance between all members of the two groups. In the constrained mode, the program runs a Monte Carlo simulation to determine whether the original matrix is more informative than a random matrix.

In the first cluster analysis, 10 copulatory measures (IF, MT/I, T/E, NT $1^{\text {st }}$ series, DC, L, EF, $\Sigma$ IF, $\Sigma$ NT and $\%$ one I) and four patterns of behavior accompanying copulation, such as the percentage of males that were singing, waltzing or marking the substrate, as well as the mean score of biting, were used. The common vole (Microtus arvalis Pallas, 1778) was used as an outgroup. In the second cluster analysis, an additional copulatory measure, namely the percentage of mounts during the whole test that were finished by sperm transfer after one thrust and falling on the side after ejaculation, was used. When 15 taxa had been compared, three modes of marking by urine (mode 1 ), by secretion from the hip (mode 2) and flank skin glands (mode 3) were noted. When constructing the second dendrogram, the data for the species obtained earlier were used (Zorenko et al., 1994; Zorenko, 2000; Zorenko \& Atanasov, 2017).

\section{Results}

Duration of courtship in voles differed markedly in different pairs. Only $25 \%$ of pairs of BP voles and $40 \%$ of pairs of UP voles began to mate in the first three minutes. In most cases, copulation happened from the fifth to tenth minute. A lot of male time involved exploration of the territory. This is probably the reason for the increased duration of courtship. Voles from AP 
Table. Quantitative parameters (the arithmetic mean \pm standard error) of copulatory behavior in the different root vole populations. For abbreviations see Materials and Methods.

\begin{tabular}{|l|c|c|c|}
\hline Measures & $\begin{array}{c}\text { Baikal population } \\
\mathrm{n}=10\end{array}$ & $\begin{array}{c}\text { Ural population } \\
\mathrm{n}=10\end{array}$ & $\begin{array}{c}\text { Alaska population* } \\
\mathrm{n}=12\end{array}$ \\
\hline EF & $4.6 \pm 0.33$ & $4.6 \pm 0.31$ & $3.2 \pm 0.2$ \\
\hline$\Sigma$ IF & $8.3 \pm 1.31$ & $5.5 \pm 1.43$ & 12 \\
\hline$\Sigma$ NT & $185.5 \pm 20.11$ & $108.2 \pm 12.32$ & 86 \\
\hline$\Sigma$ NTI & $96.7 \pm 13.02$ & $46.4 \pm 11.81$ & 60 \\
\hline$\Sigma$ NTE & $94.6 \pm 13.87$ & $61.8 \pm 7.14$ & 28 \\
\hline $\begin{array}{l}\text { The probability of occurrence of } \\
\text { intromiation during the first }\end{array}$ & $15.5 \pm 5.89$ & $47.8 \pm 10.07$ & about $10 \%$ \\
\hline IF, 1st. series & $2.3 \pm 0.58$ & $0.5 \pm 0.27$ & $3.8 \pm 0.5$ \\
\hline MT/I $1^{\text {st }}$ series & $12.5 \pm 2.80$ & $10.3 \pm 3.65$ & $8.6 \pm 1.0$ \\
\hline NTE $1^{\text {st }}$ series & $24.8 \pm 3.76$ & $18.9 \pm 3.29$ & $7.2 \pm 0.9$ \\
\hline NT $1^{\text {st }}$ series & $48.3 \pm 4.25$ & $26.8 \pm 4.81$ & 30 \\
\hline DC, s & $122.0 \pm 14.1$ & $41.5 \pm 8.50$ & $98.5 \pm 10.2$ \\
\hline PEI, s & $364.8 \pm 38.89$ & $318.5 \pm 24.4$ & $524.4 \pm 30.4$ \\
\hline L, s & $372.3 \pm 151.86$ & $495.2 \pm 189.4$ & $200.0 \pm 47.2$ \\
\hline
\end{tabular}

* data from Dewsbury \& Hartung (1982)

(Alaska population) began to mate, as a rule, during the first three minutes. However, the differences of the duration of courtship were not statistically significant (Table).

The males mainly presented behavior such as recognition (naso-anal sniffing and investigation of female urine) and following the females and waltzing (males moving in small steps around the female and trying to mount), often accompanied by singing. Grooming was not typical for the root vole (Fig. 1). Marking the territory both with urine and secretion from the hip glands occupied a significant amount of time. We reported singing during courtship in $50 \%$ of males from UP and in $60 \%$ of males from BP, as well as waltzing and marking in $60 \%$ and $70 \%$ of males, respectively, of both populations. Dewsbury and Hartung (1982) did not present data for these parameters from the Alaskan root vole population. However, Alaskan voles have hip glands which produce secretions for marking. Alaskan root voles also displayed marking behavior, such as scratching or rubbing the substrate (Feldhamer et al., 2003). The males may occasionally use vocalizations for communication (singing), although little is known about this behavior in Alaskan voles.

Males did not manifest aggression, either directly or ritualized, with regard to females, but they displayed a behavioral pattern, biting the females' back once, rare-

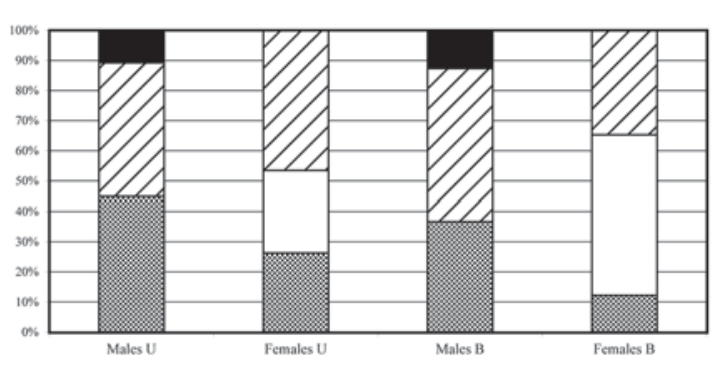

Fig. 1. Distribution of patterns of mating behavior in males and females of A.oeconomus.

Males and females U - Ural population, Males and females B Baikal population; column pattern as circles - recognition, white column - ritual aggressive contacts, column pattern as sloping lines - sexual contacts, black column - marking.

ly two times, during courtship and usually once after the copulation. Biting was not a sign of real aggression, as the female did not attempt to escape after that and the courtship continued. Perhaps, biting was a means of partner stimulation.

The frequency of marking behavior in females was significantly lower than in males (Fig.1). Their sexual contact involved running from or following the males, in order to attract a male and copulate. At the same 

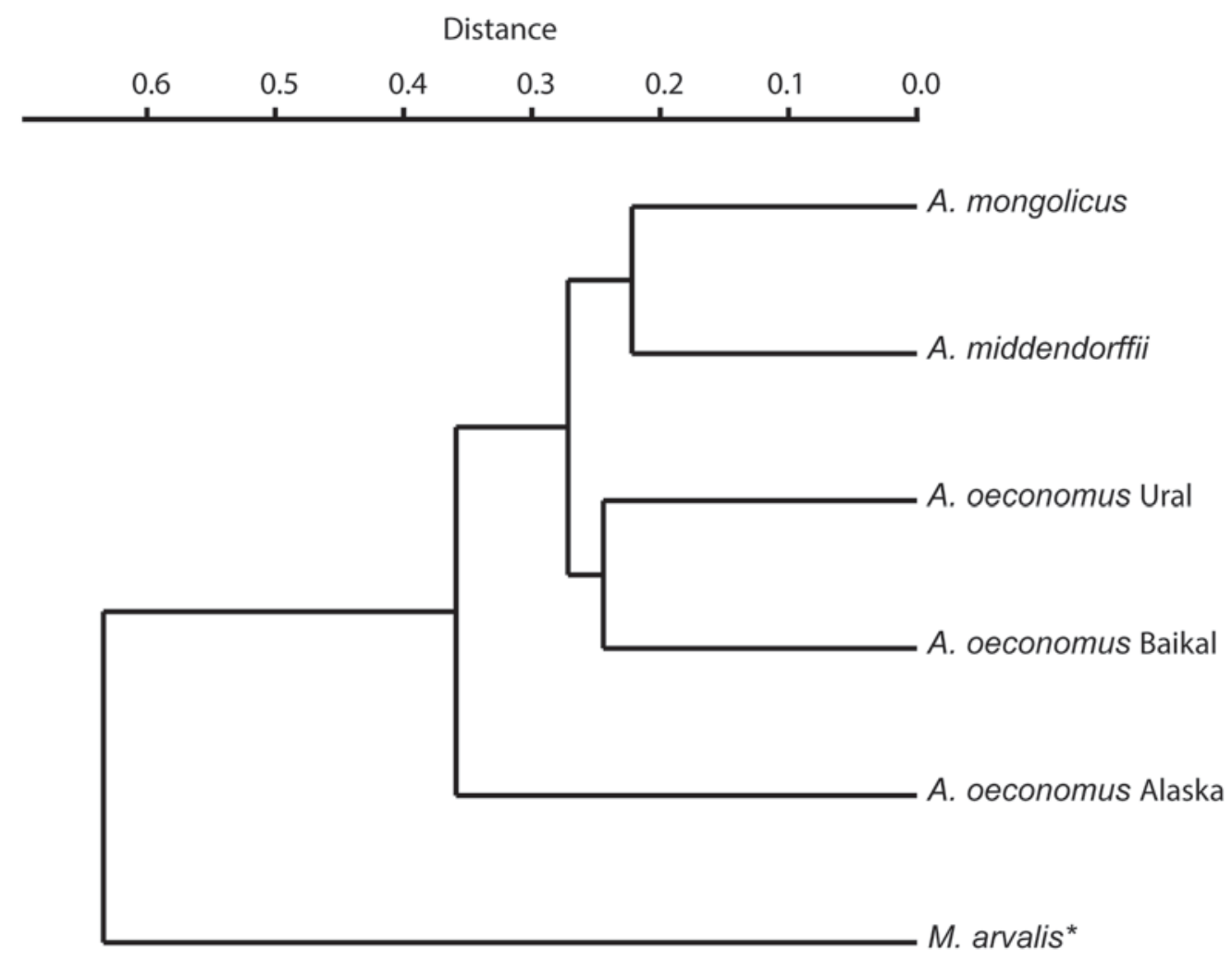

Fig. 2. Hierarchical cluster analysis dendrogram illustrating the phylogenetic relationships of some vole taxa on the base of sexual behavior signs using Gower's distances index.

time, females manifested their ritualized aggression (rearing on hind legs, pushing and vocalizing). This behavior initiated the establishing and maintaining of interactions, but did not reduce them, as has happened when there is true aggression. This behavior in females provoked the male to follow her and attempt a mount. Therefore, it can be assumed that ritualized aggression basically facilitates the synchronization of the behavior of partners and the preparation of the female for mating. This behavior characterizes females of all vole species, but to varying degrees. In the UP voles it is twice that in the Baikal voles (Fig.1). In social voles it is weakly expressed (Zorenko, 2000), whereas in the common vole Microtus arvalis the behavior of females can be significant. A receptive female displays a posture of lordosis.

The root vole is a species with multiple ejaculations: from 4 to 7 in UP voles and from 3 to 6 in BP voles per copulation (Table). The Alaskan population, in which it varied from 2 to 4 (Dewsbury \& Hartung, 1982; $<<0.01$ ), differs significantly from Ural and Baikal populations. Even with the first mount, an ejaculation was established: in the UP males, this mode of copulation was noted in almost half of the mating pairs. The percent of occurrence of first mount ejaculation in the males from BP and especially in those from UP compared with the males from AP was higher (Table) and the differences were significant $(p<0.01)$. Dewsbury and Hartung (1982) reported that sometimes the first contact of voles ended with ejaculation, but, apparent$1 y$, the number of such pairs was not more than $10 \%$.

The number of intromissions for the entire mating period in both the series and in general was small, especially in UP voles. The difference between UP and BP voles $(p<0.05)$ and between UP and AP voles $(p<0.001)$ was statistically significant (Table). The duration of copulation, as well as the post-ejaculation period, varied significantly in voles from the different populations. The lowest values of parameters were in the UP voles, while the highest values were in the BP and AP voles (Table 1).

Significant differences in the level of genital stimulation were noted. The total number of thrusts during the entire mating period $(\Sigma \mathrm{NT})$ for the BP males was 1.7 times higher in comparison with the males from UP and 2.2 times that of AP males. Index $\Sigma \mathrm{NT}$ between Ural and Alaskan populations showed a small difference (1, 3 times) (Table). Differences in the thrusts per mounts with ejaculation (NTE $1^{\text {st }}$ series) and total thrusts per ejaculation ( $\Sigma \mathrm{NTE})$ between AP and UP-BP were also demonstrated $(\mathrm{p}<0.05)$.

Seven mating parameters (IF $1^{\text {st }}$ series, NT $1^{\text {st }}$ series, DC, $\Sigma$ NT, $\Sigma$ NTI, $\Sigma$ NE and $\%$ one I) out of 13 (54\%) which were compared between BP and UP voles were significantly different. These parameters mainly related to the frequency characteristics of behavioral 


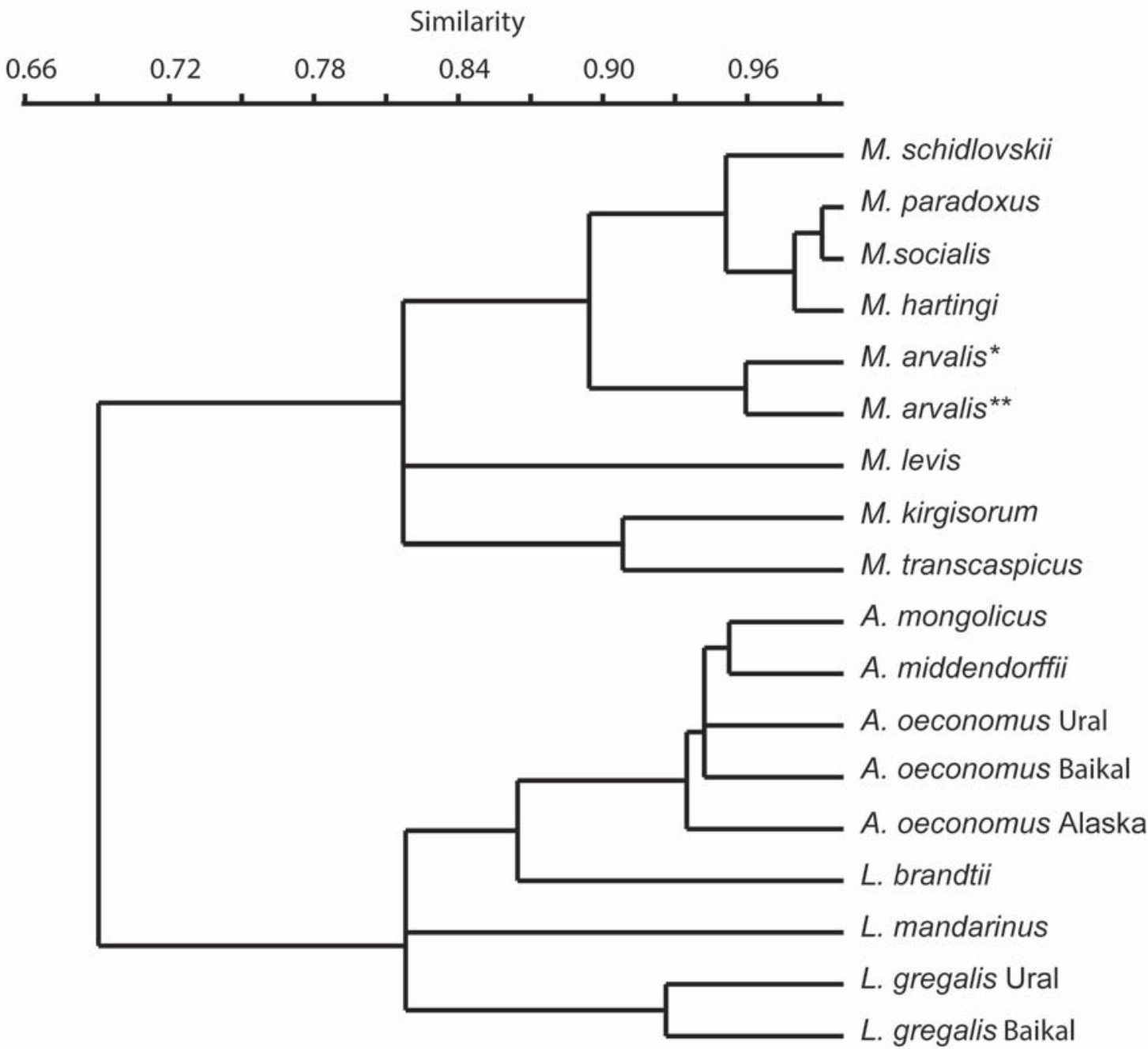

Fig. 3. Hierarchical cluster analysis dendrogram illustrating the phylogenetic relationships among 18 taxa (including the root vole $A$. oeconomus) on the base of sexual behavior signs using Cosine's similarity index. M. arvalis* - M. arvalis (arvalis), M. arvalis** - M. arvalis (obscurus).

patterns and to a lesser extent the temporary characteristics (e.g., the duration of the mating series). When comparing the Ural and Baikal voles with voles from Alaska, we revealed 10 differences (77\%). The Alaskan population differed from the Central Asian population by such indices as the EF, $\Sigma$ IF, IF 1 st series, NTE $1^{\text {st }}$ series, NT $1^{\text {st }}$ series, DC, $\Sigma$ NT, $\Sigma$ NTI, $\Sigma$ NE and PEI. Almost all of the differences were quantitative, whereas the basic type of multiple thrusting stereotype did not differ.

Cluster analysis of sexual behavior parameters for the three populations of $A$. oeconomus, as well as two species of the "mongolicus" group of the genus Alexandromys, showed increases in the degree of differences between Ural and Alaskan populations in comparison to A. mongolicus Radde, 1861 and A.middendorffii Poljakov, 1881 (Fig. 1). The construction of a phylogenetic tree with the participation of vole species from other genera showed that the root voles, together with others species of the genus Alexandromys, form an independent clade (Fig. 2).

\section{Discussion}

Morphological, molecular and cytogenetic characteristics are most often used for phylogenetic reconstruction, but it is also possible to use behavioral patterns for this purpose (Iwasa et al., 2009; Bannikova et al., 2010; Lissovsky et al., 2013, 2017). Some studies suggest that behavioral characteristics should be used whenever they are available (De Queiroz \& Wimberger, 1993). For closely related species and genera, phylogeny based on highly stereotyped behavior, such as copulation, may be important and determine the reliability of the obtained reconstructions. In this study, such copulatory behavior parameters, such as number of thrusts and intromissions leading to initiation of the ejaculation mechanism in males and the inclusion of 
neuroendocrine mechanisms in females, were used to investigate the relationship between species. Both features are most widely represented in two orders of mammals - rodents and primates (Dewsbury, 1972). In all vole species, both parameters (the number of thrusts and intromissions) are leading during the pairing and only their frequency differed. Their presence is criteria for homology of signs necessary for constructing phylogenetic schemes (Lukhtanov, 2013). When constructing the phylogenetic tree, we used the maximum parsimony method. The method makes it possible to operate with many parameters and characteristics, not only relating to the stereotype of mating, but also patterns of behavior in courtship (waltzing, singing and marking the territory), i.e. we also used potential synapomorphies.

The data obtained from the analysis of pairing behavior of $A$. oeconomus supports the separation of this species from the genus Microtus. In the species of the genus Microtus (Microtus s.str. and Sumeriomys), a multiple-intromission mating model is noted. Genital stimulation is divided into separate "quanta" (the criterion is the parting of the partners); as a result the number of intromissions increases. At the same time, a significantly lower number of ejaculations and level of genital stimulation occurs. At courtship, males rarely show waltzing and singing. They have no hip glands and, therefore, no marking behavior corresponding to their function.

In contrast, copulatory behavior of the root vole is characterized by multiple ejaculations and relatively high genital stimulation, which is expressed in a large number of thrusts and a tendency for ejaculation at the first mount which results in a small number of intromissions. This model of copulation could be described as a multiple-thrusting model, as the necessary level of genital stimulation is achieved by multiple thrusts for a short time. During courtship, males demonstrate behavior patterns such as singing, waltzing and marking with secretion from the hip gland.

The behavioral characteristics of the root vole are similar to other species of East Asian voles of the genus Alexandromys, belonging to the groups "mongolicus" (Zorenko \& Atanasov, 2017), "fortis" and "maximowiczii" (Zorenko, 2007). All species of the genus have hip glands (Quay, 1968; Aksenova, 1973) and marking with its secretion. Marking behavior is typical for males both in competitive relationships and in meetings of sexual partners. In all studied species of the genus, courtship before the beginning of copulation took place. The males were intensively vocalizing, waltzing, trying to mount females and following the females. For the entire genus, a multiple-thrusting model of copulation with a large number of ejaculations and a small number of intromissions is typical. Males often ejaculated without previous intromissions.

The divergence of the genus Alexandromys from the genus Microtus in the Early Pleistocene about $1.9 \pm$ 0.5 million years ago has been established (Abramson et al., 2009). In turn, divergence of the taxa Alexandromys and Pallasiinus is estimated to have occurred approximately 1.2 Myr (Bannikova et al., 2010). However, new data do not support the concept of dividing Alexandromys into two lineages: Alexandromys s.str. and Pallasiinus (Lissovsky et al., 2017). As the cluster analysis showed, the differences between A. mongolicus, $A$. middendorffii and $A$. oeconomus were insignificant and are manifested mainly in frequency characteristics (Figs 1 and 2).

Most species of the genus Alexandromys live in similar ecological conditions - in the forest, foreststeppe and steppe zones, preferring valleys with thick grass, wet meadows and forest glades (Meyer et al., 1996). The taxa of the "fortis" group, as well as $A$. oeconomus, occur in similar habitats and have more or less the same ecological requirements (Haring et al., 2011). However, similarity in behavior between the species Alexandromys and A. oeconomus could not be the result of parallelism caused by the influence of similar environmental conditions. This similarity may be explained by the patterns of copulation being not strictly adaptive features, the variability of which is not under the direct effect of selection. More likely, the similarity in behavior points to a single ancestor and a homology of the identified behavior patterns.

Root voles are thought to have originated in Asia, only recently entering the Nearctic via the Bering Land Bridge (Rausch, 1963; MacPherson, 1965). Their settlement in Europe occurred much earlier. Colonization predated the latest glacial period at 115 000-100 000 bp (Brunhoff et al., 2003). The root vole is the only species of the genus Alexandromys which expanded its area so significantly. Fossil data show that the root vole occurred over much of central Europe during the last glacial period, including the last glacial maximum 21 000-17 000 bp (Chaline, 1987). During the same period, the Central Asian phylogroup was widely represented behind the Urals (Markova et al., 1995). At about the same time, settlement of southern Alaska and northern Canada may have occurred, despite the territory being covered with an ice shield at that time (Zakrzewski, 1985; Andersen \& Borns, 1997).

Behavioral analysis of the root vole showed the presence of subspecies differences in behavior. The UP voles belong to the subspecies $A$. o. oeconomus Pallas, 1776 and BP to A. o. dauricus Kastschenko, 1910 (Gromov \& Erbayeva, 1995). The level of difference between the UP and BP voles is $54 \%$, which is due to males of the former subspecies ejaculating in almost $50 \%$ of cases at the first mount, so the number of intromissions is very small. In addition, they are characterized by a significantly lower level of genital stimulation. Therefore, in spite of individuals of both populations belonging to the same phylogroup, the differences between populations from the western and central part of the range are significant and are characteristic for subspecies levels. The divergence of this group 
from the Northern European phylogroup occurred before 0.29-0.49 Myr ago (Brunhoff et al., 2003).

It could be assumed that the stereotype of copulation in Northern European voles would be similar to that of UP voles. It is necessary to conduct a study of the Central and Northern European phylogroups establish the history of changes in their behavior during mating. After the divergence of these two groups, the evolution of the Central Asian phylogroup began, which actively spread to the east.

More significant differences between the Beringian group and Asian voles were established. It should be recognized that differences in the methodology used in this study may have had some effect on the results, for example, extending the courtship period (L), the duration of the copulation (DC) or the duration of the rest period. However, differences in the methodology could not lead to a decrease in the number of ejaculations (EF) or genital stimulation (ÓNT), since these behavior parameters depend on male potency and not female potency. Hormone-induced receptivity, such as occurring in the natural reproductive cycle, includes the same neuroendocrine mechanisms in females and determines the release of pheromones specific for them.

The level of divergence of UP and BP males in comparison with the Alaskan males reached up to $77 \%$ of all the behavioral traits. Cluster analysis also showed the largest divergence of the AP group from the other two groups (Fig. 3). Divergence of the Central Asian and Beringian groups occurred $0.21-0.35 \mathrm{Myr}$ ago (Brunhoff et al., 2003). Despite the differentiation of mtDNA (Brunhoff et al., 2003), as well the karyotypic (Nadler et al., 1976) and morphological (Paradiso \& Manville, 1961) signs, being low throughout the whole area of Bering's group, it could be assumed that, in the region of Chukotka and Magadan, the copulation model was undergoing changes. The copulation parameters of the voles from this part of the species area could have values which are intermediate to those of Baikal and Alaska voles. Therefore, it is highly desirable to conduct additional investigations within this phylogroup.

Attempts to explain the specificity of mating in rodents through the role of environmental factors do not give an unambiguous answer. The pressure of the predators could be one of these factors (Dewsbury, 1981a). In this case, copulation could be shorter and include fewer thrusts. However, the duration of the copulation showed little difference between the species with a multiple-intromission or multiple-thrusting copulation model (Zorenko, 2013). The features of mating in voles could also be determined by their breeding strategy. The root vole is often defined as a species with a promiscuous type of mating (Tast, 1966; Borkowska et al., 2009). However, monogamous relationships are also possible (Viitala, 1994). Moreover, even in species with typical monogamy, females often mate with many (at least two) males. However, molecular analyses have demonstrated multiple paternity in Microtus ochrogaster Wagner, 1942 litters (Solomon et al., 2004), although it is one of the typical monogamous species
(Getz et al., 1990). In A. oeconomus, 38\% of the litters are from two or three different males (Borkowska et al., 2009).

If it is promiscuity strategy, probably sperm competition could be very important. The most successful male produces up to $40-60 \%$ of the offspring and the contribution of the remaining males, especially the third male, is insignificant (Borkowska et al., 2009). Dewsbury (1981b) suggested that multiple intromissions help the male to remove a vaginal plug from the female genital tract that formed because of the ejaculation of the previously mated male, thereby increasing his contribution to future offspring. However, removal of the plug also occurs when the same male mates again. Plugs are formed by male voles with different types of pairing, since their primary function is to facilitate sperm transport (Zorenko \& Aksenova, 1989). The formation of plugs is associated with the functioning of the gonads, the prostate and the bulbourethral glands (Aksenova, 1973). Plugs do not form if there are no glands. In such cases, rodents have a different sperm transport mechanism and a special pattern of a mating behavior described as locking (Baumgardner et al., 1982).

Obviously, the breeding system does not directly affect the mating process itself, so it is not possible to identify a clear correlation between the breeding strategy and the copulation behavior. Mating systems are more evolutionarily labile than copulatory patterns and stereotypes (Dewsbury, 1981b). Therefore, the evolution of the copulatory stereotype largely reflects the phylogeny of the taxonomic group and is less dependent on environmental factors. In view of this, the comparative analysis of mating behavior and its specificity can expand our understanding in considering the phylogeny of different taxa.

Acknowledgements. We would like to express our great gratitude to researcher Yulya Kowalskaya from the A.N. Severtsov Institute of ecology and evolution of the Russian Academy of Sciences for providing the founders $A$. oeconomus from Ural population for our laboratory colony. We are grateful to the reviewers for the extensive comments and fruitful discussions of previous versions of the manuscript.

\section{References}

Abramson N.I. \& Tikhonova E.P. 2005. Reevaluation of taxonomic structure of the root vole (Microtus oeconomus Pallas, 1776, Rodentia, Arvicolidae) from the territory of the former USSR based on evidence from craniometric and molecular data // Russian Journal of Theriology. Vol.4. No.1. P.63-73.

Abramson N.I., Lebedev V.S., Bannikova A.A. \& Tesakov A.S. 2009. [Stages of radiation in the phylogeny of voles (Arvicolinae, Rodentia): Data by nuclear genes] // Reports of the Academy of Sciences. Vol.428. No.5. P.713717 [in Russian, with English summary]. 
Abramson N.I. \& Lissovsky A. A. 2012. Subfamily Arvicolinae // Pavlinov I.Ya. \& Lissovsky A.A. (eds.). The Mammals of Russia: A Taxonomic and Geographic Reference (Archive of the Zoological Museum of MSU). Moscow: KMK Scientific Press. Vol.52. P.220-276.

Aksenova T.G. 1973. [A structure of accessory sex glands in some species of grey voles of genus Microtus (Rodentia, Cricetidae)] // Zoologicheskii Zhurnal. Vol.52. No.12. P.1843-1848 [in Russian].

Andersen B.G. \& Borns H.W. Jr. 1997. The Ice Age World: An Introduction to quaternary history and research with emphasis on North America and Northern Europe during the last 2.5 million years. Oslo: Scandinavian University Press. 208 p.

Bannikova A.A., Lebedev V.S., Lissovsky A.A., Matrosov V.A., Abramson N.I., Obolenskaya E.V. \& Tesakovs A.S. 2010. Molecular phylogeny and evolution of the Asian lineage of vole genus Microtus (Rodentia: Arvicolinae) inferred from mitochondrial cytochrome $b$ sequence // Biological Journal of Linnean Society. Vol.99. P.595-613.

Baumgardner D.J., Hartung Th.G., Sawrey D.Kim, Webster D.G. \& Dewsbury D.A. 1982. Muroid copulatory plugs and female reproductive tracts: comparative investigation // Journal of Mammalogy. Vol.63. No.1. P.110-117.

Brunhoff C., Galbreath K.E., Fedorov V., Cook J.A. \& Jaarola M. 2003. Holarctic phylogeography of the root vole (Microtus oeconomus): implications for late Quaternary biogeography of high latitudes // Molecular Ecology. Vol.12. P.957-968.

Borkowska A., Borowski Z. \& Krysiukc K. 2009. Multiple paternity in free-living root voles (Microtus oeconomus) // Behavioural Processes. Vol.82. P.211-213.

Chaline J. 1987. Arvicola data (Arvicolidae, Rodentia) and evolutionary concepts // Evolutionary Biology. Vol.21. P.237-310.

Conroy C.J. \& Cook J.A. 2000. Molecular systematics of a Holarctic rodent (Microtus: Muridae) // Journal of Mammalogy. Vol.8. No.2. P.344-359.

Galbreath K.E. \& Cook J.A. 2004. Genetic consequences of Pleistocene glaciations for the tundra vole (Microtus oeconomus) in Beringia // Molecular Ecology. Vol.13. P.135-148

Getz, L.L., McGuire B., Hofmann J., Pizzuto T. \& Frase B. 1990. Social organization and mating system of the prairie vole, Microtus ochrogaster // Tamarin R.H. (ed.) Social Systems and Population Cycles in Voles. Berlin: Birkhauser Verlag. P.69-80.

Gray G.D. \& Dewsbury D.A. 1973. A quantitative description of copulatory behavior in meadow voles (Microtus pennsylvanicus) // Animal behavior. Vol.23. No.2. P.261267.

González-Flores O., Hoffman K.L., Delgadillo J.A., Keler M. \& Paredes R.G. 2017. Female sexual behavior in rodents, lagomorphs and goats // Hormones, Brain and Behavior. Third edition. G.González-Mariscal (ed.). Mammalian hormone-behavior systems. Vol.1. P.59-79.

Gromov I.M. \& Erbayeva M.A. 1995. [The Mammals of Russia and adjacent territories. Lagomorpha and Rodents]. Sankt-Peterburg: Zoologicheskii Institut. 520 p. [In Russian]
De Queiroz A. \& Wimberger P.H. 1993. The usefulness of behaviour for phylogeny estimation: levels of homoplasy in behavioural and morphological characters // Evolution. Vol.47. No.1. P.46-60.

Dewsbury D.A. 1972. Patterns of copulatory behavior in male mammals // Quarterly Review of Biology. Vol.47. No.1. P.1-33.

Dewsbury D.A. 1981a. An exercise in the prediction of monogamy in the field from laboratory data on 43 species of muroid rodents // Biologist. Vol.63. No. 4. P.138162.

Dewsbury D.A. 1981b. On the function of the multipleintromission, multiple-ejaculation copulatory patterns of rodents // Bulletin of the Psychonomic Society. Vol.18. No.4. P.221-223.

Dewsbury D.A. \& Hartung T.G. 1982. Copulatory behavior of three species of Microtus // Journal of Mammalogy. Vol.63. No.2. P.306-309.

Estep D.Q., Lanier D.L. \& Dewsbury D.A. 1975. Copulatory behavior and nest building behavior of wild house mice (Mus musculus) //Animal Learning and Behaviour. Vol.3. P.329-336.

Feldhamer G., Thompson B. \& Chapman J. 2003. Wild mammals of North America: biology, management, and conservation. Second edition. Baltimore, Maryland: Johns Hopkins University Press. 1216 p.

Haring E., Sheremetyeva I.N. \& Kryukov A.P. 2011. Phylogeny of Palearctic vole species (genus Microtus, Rodentia) based on mitochondrial sequences // Mammalian Biology. Vol.76. P.258-267.

Iwasa M.A., Kostenko V.A., Frisman L.V. \& Kartavtseva I.V. 2009. Phylogeography of the root vole Microtus oeconomus in Russian Far East: A special reference to comparison between Holarctic and Palearctic voles // Mammal Study. Vol.34. P.123-130.

Kenney A.M., Hartung Th.G. \& Dewsbury D.A. 1979. Copulatory behavior on the initiation of pregnancy in California vole // Brain, Behavior and Evolution. Vol.16. No.2. P.176-191.

Lukhanov V.A. 2013. [Phylogenetic reconstructions: characters, models of evolution and methods of phylogenetic inference] // Trudy Zoologicheskogo Instituta RAN. Supplement No.2. P.39-52 [in Russian, with English summary].

Lissovsky A.A., Obolenskaya E.V. \& Petrova T.V. 2013. Morphological and genetic variation narrow-headed voles Lasiopodomys gregalis from South-East Transbaikalia // Russian Journal of Theriology. Vol.2. P.83-90.

Lissovsky A.A., Petrova T.V., Yatsentyuk S.P., Golenishchev F.N., Putincev N.I., Kartavtseva I.V., Sheremetyeva I.N. \& Abramson N.I. 2017. Multilocus phylogeny and taxonomy of East Asian voles Alexandromys (Rodentia, Arvicolinae) // Zoologica Scripta. Vol.47. No.1. P.9-20.

MacPherson A.H. 1965. The origin of diversity in mammals of the Canadian arctic tundra // Systematic Zoology. Vol.14. P.153-173.

McGill T.E. 1962. Sexual behavior in three inbred strains of mice // Behaviour. Vol.19. P.341-350.

Meyer M.N., Golenishchev F.N., Radjably S.I. \& Sablina O.V. 1996. Voles (subgenus Microtus Schrank). Pro- 
ceedings of the Zoological Institute. Saint-Petersburg: Russian Academy of Science. 320 p. [In Russian, with English summary]

Nadler C.F., Rausch V.R., Lyaponova E.A., Hoffmann R.S. \& Vorontsov N.N. 1976. Chromosomal banding patterns of the Holarctic rodents, Cletrionomys rutilus and $\mathrm{Mi}$ crotus oeconomus // Zeitschrift für Säugetierkunde. Vol.41. P.137-146.

Paradiso J.L. \& Manville R.H. 1961. Taxonomic notes on the Tundra vole (Microtus oeconomus) in Alaska // Proceedings of the Biological Society of Washington. Vol.74. P.77-92.

Rausch R.L. 1963. A review of the distribution of Holarctic recent mammals // Gressett J.L. (ed.). Honolulu: Pacific Basin Biogeography Bishop Museum Press. P.29-44.

Rutovskaya M.V. 2015. [Variability and formation of sound communication of the voles of the subfamily Arvicolinae]. Abstract of the Thesis of Dr.Sc. degree in Biology. Moscow. 48 p. [In Russian]

Quay W.B. 1968. The specialized posterolateral sebaceous glandular regions in Microtine rodents // Journal of Mammalogy. Vol.49. No.3. P.427-445.

Tast J. 1966. The root vole, Microtus oeconomus (Pallas), as an inhabitant of seasonally flooded land // Annales Zoologici Fennici. Vol.3. P.127-171.

Zakrzewski R. J. 1985. The fossil record // Tamarin R. H. (ed.). Biology of New World Microtus. Utah: American Society of Mammalogists. P.1-51.

Solomon N.G., Keane B., Knoch L.R. \& Hogan, P.J. 2004 Multiple paternity in socially monogamous prairie voles (Microtus ochrogaster) // Canadian Journal of Zoology. Vol.82. P.667-1671.

Viitala, J. 1994. Monogamy in free living Microtus oeconomus // Annales Zoologici Fennici. Vol.31. P.343-345.

Zorenko T.A. 1990. [The ethological analysis in the taxonomy of rodents on the example of the voles of tribe Microtini of the USSR fauna] // Author's abstract of the thesis of Dr. Sc. degree in Biology. Leningrad: ZIN AN SSSR. 41 p. [In Russian]

Zorenko T.A. 2000. [Morphology of the genitals and sexual behavior of the social voles of the subgenus Sumeriomys (Arvicolinae, Microtus)] // Zoologicheskii Zhurnal.
Vol.79. No.8. P.990-999 [in Russian, with English summary].

Zorenko T.A. 2007. [Establishment of relationship of voles from Siberia and the Far East based on the analysis of their sexual behavior] // Theriofauna of Russia and adjacent territories. Proceedings of the International Meeting. Moscow: KMK Scientific Press Ltd. P.581 [in Russian].

Zorenko T.A. 2013. [Social voles of the subgenus Sumeriomys: systematics, biology and behavior]. Saarbrücken: Palmariun Academic Publishing. 541 p. [In Russian]

Zorenko T.A. \& Aksenova T.G. 1989. [Structure of genitals, sexual behavior and problem of isolating mechanisms in voles' tribe Microtini] // Aktual'nie problemi zoologii. Riga: Izdatel'stvo Latviiskogo Gosudarstvennogo Universiteta. P.111-132 [iIn Russian, with English summary].

Zorenko T. A. \& Malygin V.M. 1984. [Effects of ethological reproductive isolation mechanisms for the hybridization of three species of common voles group arvalis (Microtus, Cricetidae)] // Zoologicheskii Zhurnal. Vol.63. No.7. P.1072-1983 [in Russian, English summary].

Zorenko T. \& Atanasov N. 2017. Patterns of Behaviour as an Evidence for the Taxonomical Status of Lasiopodomys (Stenocranius) gregalis (Pallas, 1779) (Rodentia: Arvicolinae) // Acta Zoologica Bulgarica, Supplement No.8. P.189-197.

Zorenko T.A. \& Rutovskaya M.V. 2006. [Social behaviour of the reed vole, Microtus fortis (Rodentia, Arvicolinae)] // Zoologicheskii Zhurnal. Vol.85. No.8. P.983-997 [in Russian, with English summary].

Zorenko T.A. \& Skinderskaya I.A. 1996. [Estrous cycles and behavioral receptivity in social voles of the subgenus Sumeriomys (Rodentia, Arvicolinae)] // Zoologicheskii Zhurnal. Vol.75. No.10. P.1735-1747 [in Russian, with English summary].

Zorenko T.A., Smorkachova A.V. \& Aksenova T.G. 1994. Reproduction and postnatal ontogenesis of the Mandarin vole Lasiopodomys mandarinus Milne-Edwards, and a comparison with Brandt"s vole Lasiopodomys brandti Radde (Rodentia, Cricetidae) // Laboratory Animals. Vol.4. No.1 P.5-16. 